\title{
ЕКАТЕРИНА ШЕБЕТНИКОВА
}

\section{Приобретение права собственности на бесхозяйные вещи}

Право собственности, безусловно, занимает важнейшее место в системе вещных прав. В различных правовых системах мира вопрос о регулировании права собственности решается разнопланово. Однако следует отметить, что в каждом обществе данное право пользуется особым уважением: его характеризуют как священное и неприкосновенное.

Для того, чтобы возникло право собственности нужны определенные юридические факты. Такие юридические факты являются основаниями возникновения права собственности. Они могут выражаться как в виде действий (например, изготовление вещи), так и в виде событий (например, истечение срока приобретательной давности).

Выделяют первоначальные и производные основания приобретения права собственности. По первоначальному основанию право собственности возникает впервые, а объем прав не зависит от правомочий предшествующего собственника. При производных основаниях приобретения права собственности существует правопреемство, и осуществляется переход права собственности от предшествующего собственника к новому собственнику в том объеме, который был у предшествующего собственника.

Действующее гражданское законодательство предусматривает в качестве одного из первоначальных оснований приобретения права собственности возможность возникновения права собственности на бесхозяйные вещи. Правовой режим бесхозяйных вещей определяется следующими нормативно-правовыми актами:

- ГК (Гражданский кодекс Российской Федерации), часть первая от 30.11.1994 (глава 14, 15);

- Гражданский процессуальный кодекс Российской Федерации от 14.11.2002 (глава 33); 
- Федеральный закон О государственной регистрации прав на недвижимое имущество и сделок с ним от 21.07.19973;

- Постановление Правительства Российской Федерации от 17.09.2003 № 580 Об утверждении Положения о принятии на учет бесхозяйных недвижимых вещей ${ }^{4}$.

Вышеприведенный перечень нормативно-правовых актов, регулирующих вопрос правового режима бесхозяйного имущества, является основным, однако не исчерпывающим. В правовой системе Российской Федерации имеются и другие нормативноправовые акты, которые направлены на регулирование данного вопроса, в том числе на региональном и муниципальном уровне. Так, органы местного самоуправления могут принимать нормативно-правовые акты, регулирующие порядок организации работы администрации муниципального образования с бесхозяйным имуществом, которое находится на территории этого муниципального образования.

Пункт 1 ст. 225 ГК РФ определяет бесхозяйную вещь посредством перечня, включающего три вида вещей, признаваемых бесхозяйными:

- вещь, которая не имеет собственника;

- вещь, собственник которой неизвестен;

- вещь, от права собственности на которую собственник отказался.

Таким образом, конкретно определены те обстоятельства, при которых вещь считается бесхозяйной. Вместе с этим, следует учитывать и следующее обстоятельство: в том случае, если собственник недвижимого имущества умер, имущество не может быть признано бесхозяйным, поскольку у умершего собственника могут быть наследники, независимо от того, было ли открыто наследство и вступили ли в наследство наследники. Отказ собственника от вещи должен выражаться в совершении определенных действий, заключающихся в устранении от владения, пользования и распоряжения этой вещью без дальнейшего сохранения прав на нее. В то же время отказ от собственности сам по себе не влечет прекращения прав и обязанностей собственника в отношении имущества до тех пор, пока право собственности на него не приобретено другим лицом. Например, при отказе собственника от земельного участка обязанность уплаты земельного налога сохраняется за ним до момента регистрации права собственности на этот земельный участок другим лицом ${ }^{5}$.

Бесхозяйные вещи могут быть обращены другими лицами в свою собственность. Интересный факт отмечается в комментариях к Гражданскому кодексу РФ под редакцией А.П. Сергеева относительно вопроса о возникновении права собственности на

3 СЗ РФ. 1997 № 30, Ст. 3594.

4 С3 РФ. 2003 № 38, Ст. 3668.

5 Сборник методических рекомендаций по регулированию вопросов выявления, учета и приобретения в собственность бесхозяйного имущества [online]. Ассоциация «Совет муниципальных образований Новгородской области» [Доступ: 2013-05-15]. Доступны на: www.smono.ru/files/6212690.doc>. 
бесхозяйное имущество. В советский период этот вопрос решался на основании презумпции государственной собственности, т.е. пока иная принадлежность имущества не доказана, предполагалось, что собственником имущества является государство. В настоящее время эта презумпция потеряла свое значение и заменена предположением права собственности фактического владельца, согласно которой владелец имущества предполагается его собственником, пока не доказано иное 6 .

Понятие бесхозяйной вещи охватывает несколько видов вещей, обладающих различным правовым режимом. Так, с юридической точки зрения вещи делятся на движимые и недвижимые.

\section{1. Рассмотрим бесхозяйные вещи, относящиеся к движимым вещам:}

- брошенные собственником или иным образом, оставленные им вещи;

- находка;

- безнадзорные животные;

- клад.

\section{1 Брошенные собственником или иным образом, оставленные им вещи}

Статья 226 Гражданского кодекса РФ устанавливает, что движимые вещи, от которых собственник отказался - это брошенные собственником или иным образом, оставленные им вещи с целью отказа от права собственности на них. Такие вещи могут быть обращены другими лицами в свою собственность.

Если вещи брошены на какой-либо территории (земельном участке, водоеме, в здании, сооружении), принадлежащей не собственнику данных вещей, а другому лицу, то это лицо имеет право обратить данные вещи в свою собственность. При этом необходимо учесть, что такое право возникает у него не на все вещи, а только на:

- брошенные вещи, стоимость которых явно ниже суммы, соответствующей пятикратному минимальному размеру оплаты труда;

- брошенные лом металлов, бракованная продукция, топляк от сплава, отвалы

и сливы, образуемые при добыче полезных ископаемых, отходы производства

и другие отходы.

То есть предметы, находящиеся на земельном участке, водоеме или на каком-либо другом объекте поступают в собственность фактического владельца этих объектов, которому для этого достаточно приступить к использованию брошенных вещей. Осталь-

6 А.П. Сергеев, ред., Комментарий к гражданскому кодексу Российской Федерации. Часть первая: Уч.-практ. комментарий (постатейный), Москва 2011. 
264 | Adam Mickiewicz University Law Review

ные брошенные вещи поступают в собственность лица, вступившего во владение ими, только в том случае, если они признаны судом бесхозяйными ${ }^{7}$.

Признание вещи бесхозяйной осуществляется в судебном порядке по правилам особого производства. При этом суд должен установить следующие факты: действительно ли статус вещи - брошенная вещь, действительно ли отсутствует собственник, и его невозможно установить, и имеются ли доказательства, свидетельствующие о вступлении заявителя во владение вещью.

Такое заявление вправе подать фактический владелец вещи. Он должен указать, какая конкретно вещь подлежит признанию бесхозяйной, отметить ее отличительные признаки и представить доказательства того, что собственник отказался от права собственности на вещь, а фактический владелец-заявитель вступил во владение ее. Отсюда следует, что и законодатель, и правоприменитель подчеркивает, признает и требует исполнения принципа неприкосновенности, священности права собственности. Судебная практика показывает, что суд при принятии решения о признании вещи бесхозяйной и передаче ее в собственность фактическому владельцу, должен убедиться, что вещь была оставлена собственником без намерения сохранить право собственности на нее. Но при этом, до вступления в силу решения суда, у собственника есть возможность вернуть себе вещь. После же вступления в силу решения суда, фактический владелец вещи приобретает право собственности на нее.

\section{2 Находка}

Второй вид бесхозяйных вещей, относящихся к движимым, - находка. Как отмечает А.П. Сергеев, это движимая вещь, выбывшая из владения собственника или иного управомоченного на владение лица помимо их воли вследствие потери, и кем-либо обнаруженная. Квалифицирующим признаком находки является случайность, как потери, так и нахождения. Этим находка отличается от брошенной вещи ${ }^{8}$.

По общему правилу у лица, нашедшего потерянную вещь, возникает обязанность немедленно уведомить об этом лицо, ее потерявшее, либо собственника вещи или кого-либо другого из известных ему лиц, имеющих право получить эту вещь, и возвратить найденную вещь этому лицу. Встречаются такие ситуации, когда вещь найдена в помещении или в транспорте - нашедший вещь обязан сдать ее лицу, представляющему владельца этого помещения или средства транспорта. Сохранение вещи в целости и сохранности до ее передачи в органы власти или лицу, управомоченному на ее получение, - это обязанность нашедшего вещь. Однако ответственность за утрату или повреждение найденной вещи он несет лишь в случае умысла или грубой неосторожности и в пределах стоимости вещи.

7 В.И. Казанцев, Находка по российскому гражданскому законодательству (алогизмы, пробель и противоречия). Справочно-правовая система. КонсультантПлюс.

8 А.П. Сергеев, Ю.К. Толстой, ред., Гражданское право, В 3 m. Т. 1, Москва 2005, С. 422. 
Согласно ст. 228 ГК РФ в случае, если по истечении шести месяцев с момента заявления о находке в соответствующий орган лицо, управомоченное получить найденную вещь, не будет установлено или само не заявит о своем праве на вещь, нашедший приобретает право собственности на эту вещь. Необходимо отметить, что начало течения данного срока законодатель связывает не с моментом потери собственником вещи, а именно с моментом ее обнаружения и заявления об этом нашедшим в органы полиции или местного самоуправления9.

Находка, в отличие от рассмотренного ранее понятия брошенных вещей (вещей, от которых собственник отказался), не предполагает установление воли собственника на отказ от его права собственности на принадлежащее ему имущество. Воля собственника вещи может быть установлена, когда точно известна его личность, и он ее может подтвердить. Таким образом, находкой не будет признана вещь, если установлено намерение лица отказаться от права собственности на принадлежащее ему имущество, а также в том случае, когда нашедший вещь взял ее в месте, явно отведенном владельцем для ее хранения.

Интересным моментом является то, что законодательно ни за лицом, нашедшим вещь, ни за полицией или органом местного самоуправления не признается обязательность поиска лица, потерявшего вещь, или собственника вещи, или других лиц, имеющих право получить эту вещь. И в этом случае, на мой взгляд, не обеспечивается должная защита законных прав и интересов титульного собственника вещи.

Закон также не предусматривает обязанности нашедшего вещь публично объявлять о находке в средствах массовой информации. Более того, если ранее по советскому законодательству присвоение находки считалось преступлением, то действующий Уголовный кодекс Российской Федерации от $13.06 .1996^{10}$ такого состава преступления не содержит. По нынешнему законодательству лицо, утаившее находку либо не заявившее о ней, не несет никакой юридической ответственности; оно только утрачивает право на вознаграждение за находку в случае, если владелец этой вещи обнаружится и потребует ее возвращения.

\section{3 Безнадзорные животные}

Обращение в собственность безнадзорных животных в целом осуществляется в том же порядке, что и обращение в собственность находки. Одним из значимых вопросов правоприменительной практики в данной сфере является вопрос об объекте отношений, о том, каких животных надлежит относить к домашним. Очевидно, что не могут быть отнесены к этой категории животные, обитающие на воле, а также в искусствен-

9 Приобретение права собственности на находку и безнадзорных животных[online]. Superinf.ru [Доступ: 2013-06-07]. Доступны на: <http://www.superinf.ru/view_helpstud. php?id $=343>$.

10 СЗ РФ. 1996 № 25, Ст. 2954. 
но созданной среде обитания. Безнадзорным считается скот, заблудившийся, отбившийся и вообще выбывший из стада того или иного хозяйства. Если безнадзорный скот пристает к стадам или табунам других хозяйств, он считается пригульным ${ }^{11}$.

Пробел относительно отсутствия прямой обязанности поиска собственника вещи, имеющийся при правом регулирования находки, восполняется при регулировании соответствующего вопроса в случае с безнадзорными животными. Пункт 1 статьи 230 ГК РФ прямо предусматривает обязанность полиции или органов местного самоуправления предпринять меры к розыску собственника животных.

Норма, регулирующая срок приобретения права собственности на безнадзорных животных лицом, у которого животные находились на содержании и в пользовании - шесть месяцев с момента заявления о задержании животных аналогична норме о находке. В течение шести месяцев гражданин является владельцем задержанных им безнадзорных домашних животных. Если в течение данного периода обнаружится собственник животных, то право владения прекращается, а право собственности у юридического собственника восстанавливается в полном объеме. Здесь закон учитывает особенность животных как вещей - собственник животных (после перехода их в собственность другого лица) вправе истребовать животных в случае, если у них сохранилась привязанность к прежнему хозяину или новый собственник обращается с ними жестоко или ненадлежащим образом.

\section{4 Клад}

При характеристике клада законодатель определяет его как сокрытые (требующие раскопок или поиска) деньги или иные ценные предметы, собственник которых не может быть установлен либо в силу закона утратил на них право. Ценности могут быть спрятаны на земельном участке или в строении, представлять собой вещи, которые исключены из современного экономического оборота. Поскольку собственник их неизвестен, клад поступает в собственность гражданина или юридического лица, которому принадлежит имущество, где клад был сокрыт, и лица, обнаружившего клад, в равных долях. Если клад был обнаружен лицом, которому принадлежит земельный участок или иное имущество, где он был сокрыт, то он переходит к нему целиком.

Основанием приобретения права собственности на клад являются действия по его раскопкам или поиску и нахождение ценностей в земельном участке, строении определенного лица.

Г.Ф. Шерешеневич предлагает два критерия, согласно которым находка отличается от клада:

- клад - намеренно скрытая вещь, тогда как находка - вещь потерянная;

11 Приобретение права собственности на находку и безнадзорных животных[online]. Superinf.ru [Доступ: 2013-06-07]. Доступны на: <http://www.superinf.ru/view_helpstud. php?id=343>. 
- хотя в том и другом случае собственник неизвестен, находка основывается на том предположении, что собственник может быть найден, тогда как клад внушает предположение, что отыскание собственника уже невозможно ${ }^{12}$.

\section{2. Перейдем к рассмотрению особенностей бесхозяйных недвижимых вещей}

Законодательством устанавливается особый порядок приобретения права собственности на бесхозяйную недвижимую вещь. На первом этапе необходимо принятие такой вещи на учет в качестве бесхозяйной органом, осуществляющим государственную регистрацию прав на недвижимое имущество. Затем по истечении года со дня постановки бесхозяйной недвижимой вещи на учет орган, уполномоченный управлять муниципальным имуществом, может обратиться в суд с требованием о признании права муниципальной собственности на эту вещь. Бесхозяйная недвижимая вещь, не признанная по решению суда поступившей в муниципальную собственность, может быть вновь принята во владение, пользование и распоряжение оставившим ее собственником либо приобретена в собственность в силу приобретательной давности. То есть право собственности на бесхозяйную недвижимость может возникнуть на основании признания этого права в судебном порядке, причем данный юридический факт может повлечь возникновение только муниципальной собственности. В частную собственность бесхозяйное недвижимое имущество может перейти только на основании приобретательной давности.

Признание права муниципальной собственности на бесхозяйное имущество тесно связано с вопросами управления и распоряжения муниципальной собственностью. Поступление в муниципальную собственность по решению суда бесхозяйного недвижимого имущества не только позволяет сохранить его от разрушения и разграбления, но и дает возможность использовать это имущество в соответствии с действующими законодательными нормами, что, в свою очередь, служит источником пополнения местного бюджета.

Подводя итог всему вышесказанному, важно отметить, что на сегодняшний день законодательство РФ признает право собственности как основополагающее вещное право. Все остальные вещные права имеют производный характер. В случае возникновения ситуации, когда вещь по каким-либо причинам оказывается бесхозяйной, нормы права учитывают интересы, как титульного, так и фактического владельца.

Неизвестность собственника не является основанием для признания вещи бесхозяйной. Отсутствие сведений о собственнике вещи само по себе не может указывать на

12 Г.Ф. Шерешеневич, Учебник русского гражданского права (по изданию 1907 г.), Москва 1995, С. 196. 
268 | Adam Mickiewicz University Law Review

бессубъектность прав на нее. Во всех подобных ситуациях речь может идти о вещах, которые имеют собственника, но которые помимо его воли и при наличии установленных законом условий (как правило, это истечение определенного срока) могут перейти в собственность другого лица. Именно такие последствия наступают при невостребовании в течение определенного срока потерянной вещи, безнадзорных животных, при истечении срока приобретательной давности. Более того, истребование зачастую может оказаться вообе невозможным, например, если собственник не знает, где находится вещь и утратил за истечением установленного законом срока право на ее возврат.

До того момента, пока новый собственник не вступит в свои права, прежний собственник, не владея принадлежавшей ему вещью, все же остается таковым и вправе истребовать ее у таких фактических владельцев. Тем самым, право собственности остается священным, так как никто не может быть лишен данного права, иначе как по решению суда. Права всех собственников подлежат судебной защите равным образом.

\section{Биографическая аннотация:}

Екатерина Шебетникова - Иркутский государственный университет, Юридический институт, отделение международного права. Научные интересы: международное публичное право, международное частное право, гражданское право, сравнительное правоведение, защита прав человека.

\section{SUMMARY}

\section{The acquisition of property right of unclaimed property}

The study aims at an evaluation of the acquisition of the ownership of the unclaimed property. The author present this form of the acquisition of the right to property in the Russian Civil Code emphasising the necessity of fulfilling law norms.

KEYWORDS: acquisition of property right unclaimed property, civil law 